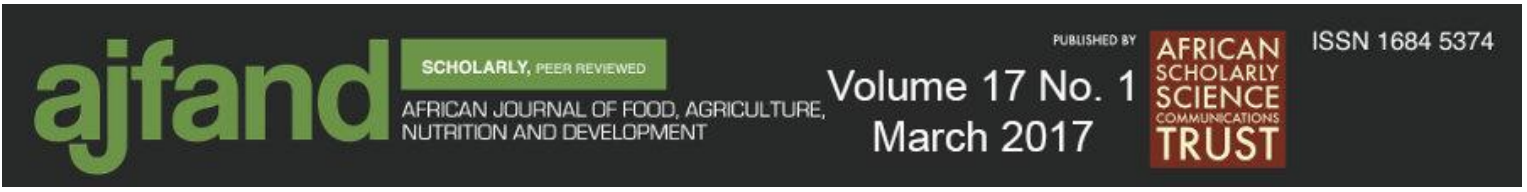

Afr. J. Food Agric. Nutr. Dev. 2017; 17(1): 11616-11638

DOI: 10.18697/ajfand.77.16765

\title{
DESIGN OF A HACCP PLAN FOR INDIGENOUS CHICKEN SLAUGHTER HOUSE IN KENYA
}

$$
\text { Oloo BO*1, Mahungu S', Gogo L }{ }^{1} \text {, A Kah }{ }^{2}
$$

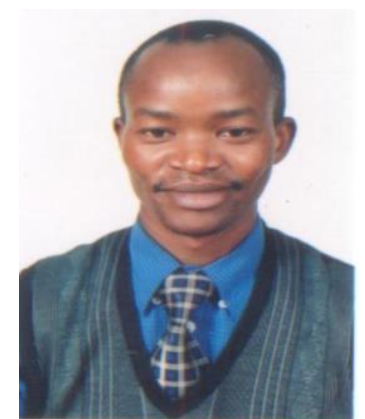

Benard Oloo

*Corresponding author e-mail: olooo.odhiambo@gmail.com

${ }^{1}$ Department of Dairy and Food Science and Technology, Egerton University, P.O Box 536, Egerton, Kenya

${ }^{2}$ Department of Animal Science, Egerton University, P.O Box 536, Egerton, Kenya 


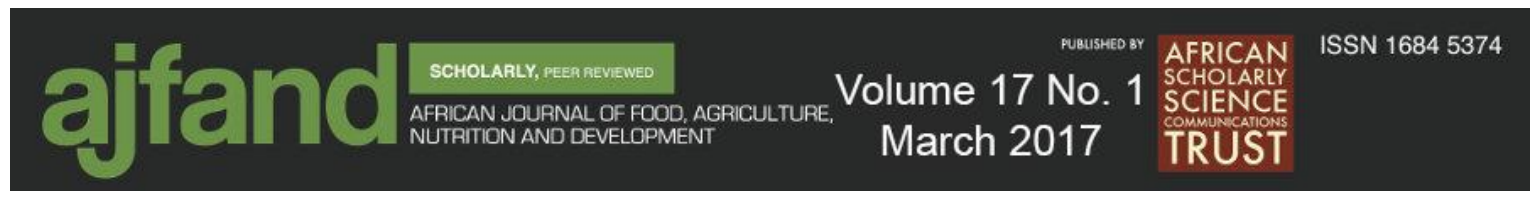

\begin{abstract}
Indigenous chicken rearing is seen as a poverty alleviation and food security strategy especially in rural households in Africa. Chicken meat is a delicacy in almost every household in Kenya. It is a common food in restaurants and hotels that serve fast foods in urban areas. Demand for and consumption of indigenous chicken meat in Kenya has been on the rise. Many slaughterhouses have been set up in strategic locations close to towns or in towns to allow for quick supply of the dressed chicken carcass to consumers. Poultry meat is a low acid food and has been associated with the presence of foodborne pathogens such as Campylobacter, Escherichia coli, Salmonella enteritidis, and Staphylococcus aureus, especially when processing conditions are not hygienic. Hazard Analysis and Critical Control Point (HACCP) is based on a scientific verifiable process to identify, control, reduce or eliminate any potential hazards to guarantee food safety. The current study was conducted based on the actual production conditions of the slaughter house. It was initiated through a survey that looked into the operations of the slaughter house on the basis of good manufacturing practices, as well as standard operation and sanitation procedures. From the results of the study and the gap audit analysis based on a checklist, the HACCP study was commissioned. The study aimed at developing a HACCP system; based on the seven HACCP principles and a critical scrutiny of several existing models. Four Critical Control Points (CCPs) were identified and a HACCP plan, complete with perquisite programs was presented to deal with the identified hazards and, therefore, present the consumers with high quality and safe products. Design of a model for the application and operationalization of HACCP system was undertaken as an important step in ensuring consumers enjoy safe products from the indigenous chicken meat prepared from the slaughter house.
\end{abstract}

Key words: Indigenous chicken, slaughter house, HACCP, Critical control points (CCPs) 


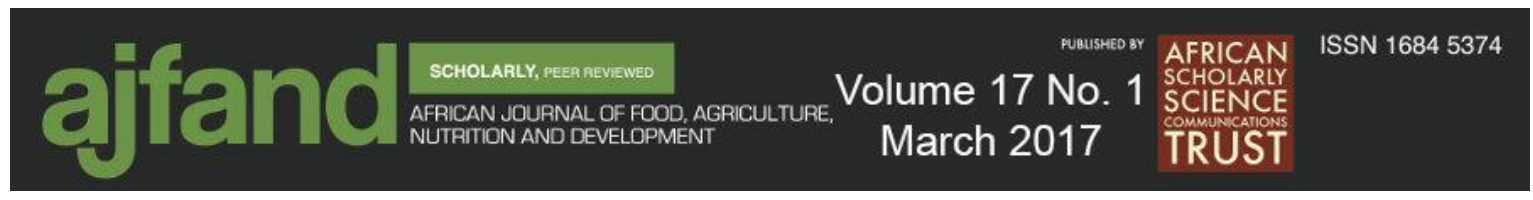

\section{INTRODUCTION}

There is currently a high demand of highly nutritious and safe food products [1]. The need for provision of high quality and safe indigenous chicken products is, therefore, no exception. Many systems have been put in place by manufacturers to try and achieve this aim. The HACCP is an acronym for Hazard Analysis and Critical Control Point. It is a scientific system which was developed to assure pathogen free foods [2]. Ropkins and Beck indicated that HACCP has been widely recognized as a rational and effective means of achieving safe food products through its application of 'from the farm to fork' approach and it is aimed at providing a step by step control of pathogens throughout processing [3]. It forms the basic preventive measure for the control of pathogens in foods [4]. Its success lies in its reliance on preventive approaches in dealing with potential pathogens in foods [1].The HACCP concept was first developed in the 1950s, through a collaboration of Pillsbury Company, the US Army's Natick Laboratory, the US National Aeronautics and Space Administration (NASA), and the US Army's Airforce Space Laboratory [5]. It was developed in response to the failure of end-use product testing to assure food safety and decrease final product wastage $[6,7,8]$.

Hazard Analysis and Critical Control Point (HACCP) was first presented to the public as a food safety system in 1985 following a paper report by the National Academy of Sciences. From then on, the concept gained wide recognition as a food safety concept in the food industry [9].The first international definition of HACCP was given in 1993 when Codex Alimentarius Commission presented its HACCP standard. By the year 2000, many factories and companies had developed a number of safety standards which led to problems in implementation of third party audits and certification. This led to the development of International Organization for Standardization (ISO) standards and especially ISO 22,000 which became known as a food safety management system [10]. The core of ISO 22,000 standard is the development and operationalization of a HACCP system. Hazard Analysis and Critical Control Point (HACCP) has become globally recognized as a food safety system based on its preventive approach to eliminate potential chemical, biological, and physical hazards. Unlike end-use product testing, HACCP leads to reduction in the occurrence of foodborne illnesses. Hazard Analysis and Critical Control Point (HACCP) is used to control occurrence of food-borne diseases by applying control systems at points within the production chain where food safety hazards could be controlled, eliminated, or reduced to within acceptable levels. It is a system of evaluation and control over the whole process to guarantee safe foods to consumers [4]. Hazard Analysis and Critical Control Point (HACCP) maintains the wholesomeness and safety of meat and poultry products because all potential hazards are anticipated, identified, characterized, eliminated or reduced to an acceptable level at each stage of the process. Hazard Analysis and Critical Control Point (HACCP) is a product and facility specific system [1]. Each facility is required to institute a HACCP system for each of the products or product lines it produces. Poultry meat processing industry in Kenya is only slightly developed and is dominated by the Kenchic industries which mostly process the exotic broiler. Processing of indigenous chicken in Kenya is at its infancy and none of the slaughter houses dealing with the indigenous chicken (IC) are currently HACCP certified for the production of high quality meat products to the consumers. 


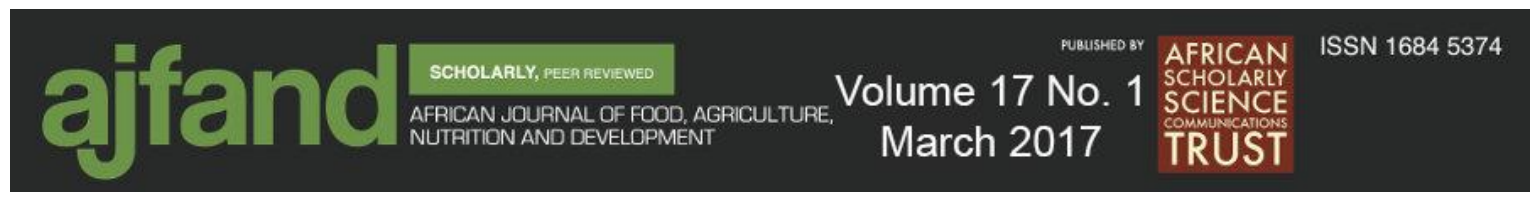

Poultry meat is a low acid food and has been associated with the presence of foodborne pathogens such as Campylobacter, Escherichia coli, Salmonella enteritidis, and Staphylococcus aureus [11, 12]. The design of a model for the application and operationalization of a HACCP system was viewed as an important step in ensuring that safe chicken meat products from indigenous chicken prepared in these slaughter houses reach the consumers. This is because it is based on a scientific verifiable process to eliminate or reduce any potential hazards relevant to food safety. This study was carried out to develop a HACCP model based on the actual processing conditions of the slaughterhouse. It developed a HACCP system based on seven (7) HACCP principles for operation in a poultry slaughter house in Nakuru County in Kenya. Its successful implementation will help prevent the occurrence of food safety hazards in the final product.

\section{MATERIALS AND METHODS}

This study was conducted in a poultry slaughter house which processes indigenous chicken, located in Nakuru County in Kenya. The slaughter house is jointly owned by the municipal council and over thirty (30) traders who supply it with chicken for processing (dressing). The slaughter house is a small-scale processing unit with a capacity to process about one thousand chickens per day. The development of the HACCP programme was supported by Nakuru County through the county veterinary office in its bid to ensure a supply of high quality and safe indigenous chicken products to its dwellers.

\section{Quality objectives}

The slaughterhouse's quality objective was to supply its customers with safe IC products of highest quality by implementing the HACCP system that ensures a safe processing environment free from all important potential contaminants. To achieve this, it will create and maintain strong relations with farmers, employees, the county administration, and other business partners while operating within the national and international regulations relevant to the business.

\section{Application of HACCP system}

The National Advisory Committee on Microbiological Criteria for Foods outlined five (5) preliminary steps and seven (7) principles in the development of a HACCP plan. Borrowing from these guidelines, the current study was conducted as follows:

\section{Preliminary Steps}

The support of the district veterinary officer, the senior management of the facility, and the county director of veterinary services was sought and obtained in writing.

- A team was formed which included: production in charge, representatives of the traders, resident veterinarian, consultant of food hygiene and sanitation, consultant of food microbiology and a technician from Egerton University laboratory. 


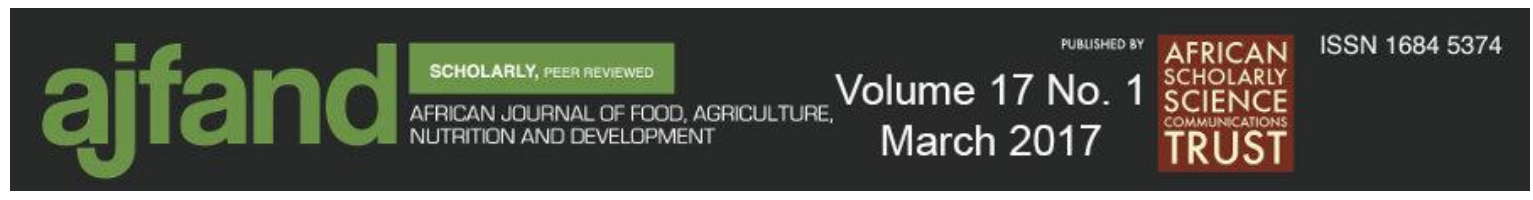

- The team engaged in the product description in terms of raw material (live birds), ingredients, processing, packaging, storage, and distribution.

\section{Product description records table}

The product was described as: Dressed frozen or chilled indigenous chicken ' $k u k u$ kienyeji' prepared based on HACCP principles for cooking before consumption. The detailed summary of the product description is presented in Table I.

\section{The development of the flow diagram:}

Each step in the process was outlined in sequence in the flow diagram (Figure 1) from raw materials through processing, packaging, and storage. In order to identify the hazards the following actions were undertaken:

Observation of operations: Each product preparation process was observed for: receipt of raw materials, storage, heat treatment, cooling, and packaging. Furthermore, the use of any additives, temperature, and packaging and storage conditions was thoroughly scrutinized. Structured questions were developed and administered to the traders and suppliers. These were used to understand the history and nature of the raw material (live birds) received. The personnel (hygiene, education, health, cleanliness, habits) and premises (equipment, floors, walls, and ventilation) working conditions were scrutinized and recorded.

Measuring operations, including adequate time and temperature to be applied, was recommended and recorded during the production storage, display, and distribution of the poultry carcass on the flow diagram.

The evaluation of the physical, chemical, and biological hazards was then conducted based on HACCP guidelines.

\section{Research method}

This study was a follow up to quantitative research that was used to survey and enumerate the occurrence and prevalence of foodborne pathogens by swabs from the different surfaces of the slaughter house. This acted as the baseline survey that helped to set the target for the developed HACCP system [13]. The current study did not use quantitative research, but qualitative techniques. The aim of this work was to design a HACCP model for implementation in an actual food operation situation. According to Patton [14], qualitative approaches are preferred where it reveals complex details of phenomena which are not easy to compile and convey quantitatively. A HACCP plan, based on the actual conditions of the premise, was developed with the aim of improving the chicken quality and safety using HACCP principles and many more carefully selected and studied generic models [15].

\section{RESULTS}

\section{Prerequisite Programmes (PRPs)}

An assessment of the PRPs was conducted according to Codex general principles of food hygiene and Good Manufacturing Practices (GMPs) [10]. The study revealed the basic 


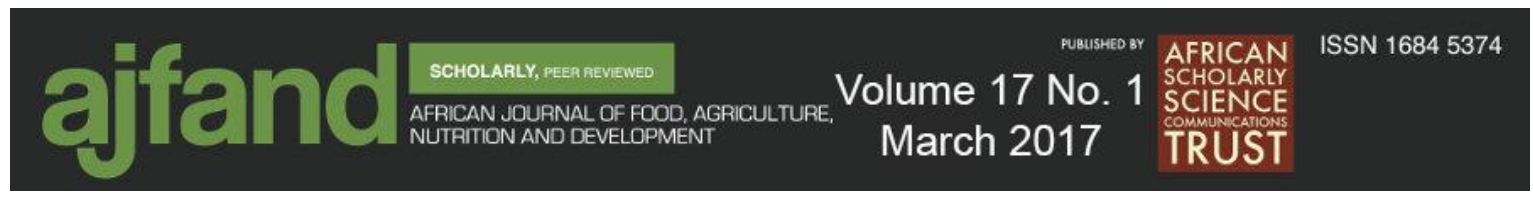

conditions of the premise for suitability of producing and handling safe chicken at every stage of the product. The major areas for consideration were as follows:

\section{Location of the slaughterhouse}

The location of the poultry slaughter house presents serious threats to food safety given the bustling of activities surrounding the slaughter house. However, additional security by cages and a fence, and its positioning at the corner of the market enhances its security as every unauthorized person to the premise can easily be monitored and stopped. Pest control operations for the premise benefit from the municipal council's regular pest control services. However, the premise can benefit more from a contracted focused pest control system.

\section{Physical condition of the premise and room}

The premise was originally designed to permit good food hygiene practices and protection from cross contamination. The walls are water, insect and rodent proof; however, deterioration of the premise and aging of the facility presents a critical challenge to food safety. Renovations were suggested in all the major areas to create a slope of $0.1 \mathrm{~m}$ per $6 \mathrm{~m}$ on the floor and installation of a self-closing door. In addition, further improvements to replace all the surfaces coming into contact with food with stainless steel equipment were agreed upon. A suitable sanitation procedure for personal hygiene and cleaning was also generated in agreement with the management.

\section{State of Equipment}

Table surfaces were made of cement, a mixture of plastic, and some painted surfaces. It was recommended that all food contact surfaces be made of stainless steel to provide for ease of cleaning, adequate sanitation and disinfection. All cracks and dents were recommended to be totally covered.

\section{Water Supply}

The slaughter house is fed with water from the municipal council water treatment plant and has make-shift storage tanks for water. The capacity of the storage tanks were inadequate should the main supply system experience any challenges or shortages. A 10,000-liter capacity tank should be installed for adequate water reserve. However, due to its location in Nakuru's Central Business District (CBD), the premise has never experienced any loss of water supply. The water quality was potable and conformed to Kenya Bureau of Standards requirements for drinking water.

\section{Maintenance and cleaning}

The establishment and equipment were cleaned occasionally. Repairs had not been undertaken for a long time and the facility was broken down in several areas. The maintenance, sanitation, and cleaning procedures were drawn and put in place for implementation by the management.

\section{Pest Control}

The slaughter house has not specifically engaged an independent pest control contractor nor does it practice its own eradication. However, it is served with Nakuru Municipal Council pest control programme for the whole municipal council market. A pest control 


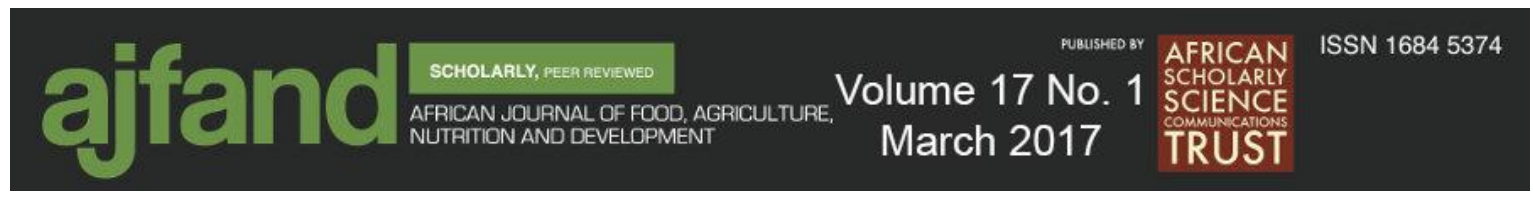

schedule/procedure and an alternative of outsourcing of this process was suggested and documented.

\section{Waste Management}

A daily waste disposal system is run through the county garbage collection scheme. Liquid waste is connected directly to the county council sewerage treatment unit. This calls for a mechanism for prevention of any accidental contamination from reverse flow of waste due to technicalities. Regular waste (feathers and other process refuse) collection, covering/separation, and classification of waste were advised. The quality control checks on national standards for releasing of waste and discharge of waste water should also be done and standards adhered to.

\section{Sanitization System}

There is a sanitation (toilet) facility accessible to the public as well; hence it is difficult to control personnel use of the facility. Remodeling of the premise to include tight sanitation and cleaning of hands and feet, and to allow proper handling of proper protective equipment (PPE) was recommended.

\section{Personal hygiene}

Implementation of hygienic practices for personnel handling, production, packaging, storage, sale of chicken and products occurred. The code to use aprons, head covers and foot wears were in place. Sanitizers for hands and foot baths were recommended. Medical checkup and issuance of a food handler's certificate for all workers was proposed and its adherence monitored. The personnel cleanliness and hygiene monitoring was instigated. The same was proposed for visitors and any other contractors who may come into contact with the facility.

\section{Storage and transportation}

The storage facility lacked temperature and humidity controlled conditions that could possibly expose chicken to fast deterioration and microbial proliferation. Most of the products were sold within the day, but the food safety concern remained real. A cold store display unit, complete with a temperature monitoring gauge and temperature/humidity log was proposed. General cleanliness and separation of food items from the slaughtered chicken unit was also implemented.

\section{Traceability}

Currently, the only traceability in place is in terms of business owner but not individual chicken product, which leaves a gap in implementation of any recall procedures in case of a food-borne illness outbreak. The First in First Out (FIFO) approach to traceability was incorporated with a traceability index including batch number, incoming date, production date, and live and dressed weight was recommended. A formal procedure for handling of customer complaints was also drawn.

\section{Training}

A training schedule was drawn for employees and designed to take into consideration the following: 


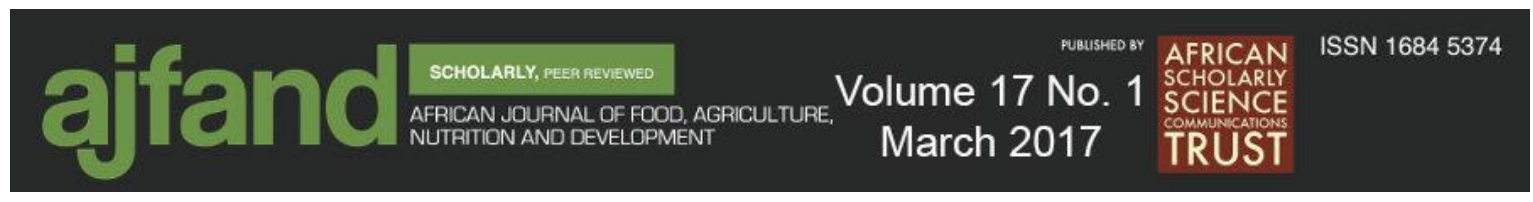

Training for newcomers, retraining for those rejoining the premise after some time, and mandatory periodic training after every 3 months on personnel hygiene, Occupational Health and Safety (OHS), production procedures, food safety, cleaning and sanitation, waste management, and environmental health management.

\section{Production Process}

The chickens are received at the reception bay from traders who transport them by bicycles, cars, or by hand. The chickens are inspected first by the traders, and then by the veterinary officer for general health and any manifestations of pests. Once passed, the chickens are held in cages of a capacity of about 10 birds each, even though these cages are often over crowded due to their limited capacity. The chickens remain in the cages until the time for slaughter and dressing according to demand. Processing occurs according to the flow diagram given in (Figure 1). 

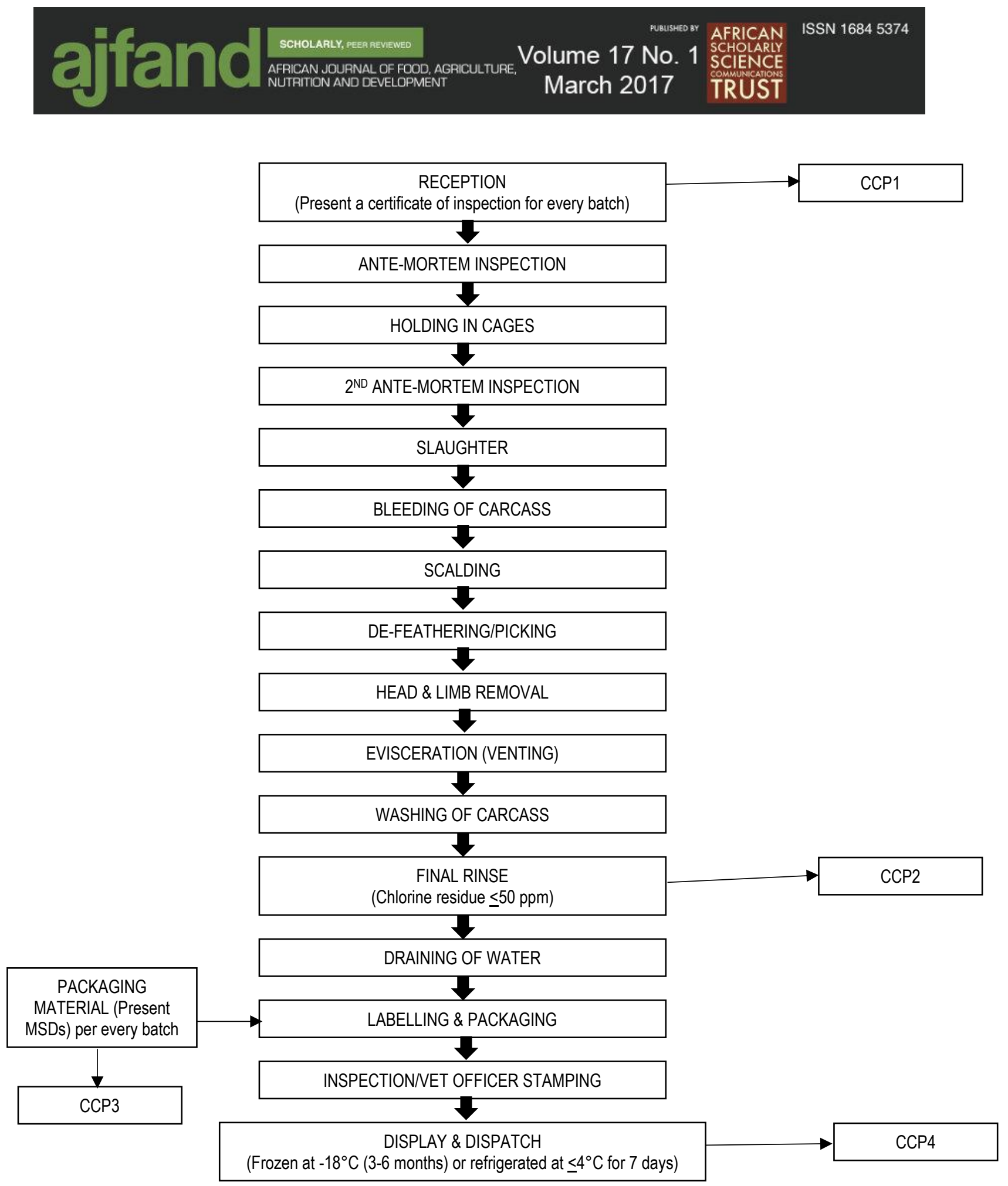

Figure 1: Flow diagram for the processing of indigenous chicken at the Nakuru top market slaughter point Legend

MSD- material safety data sheets

CCP- Critical Control Point 


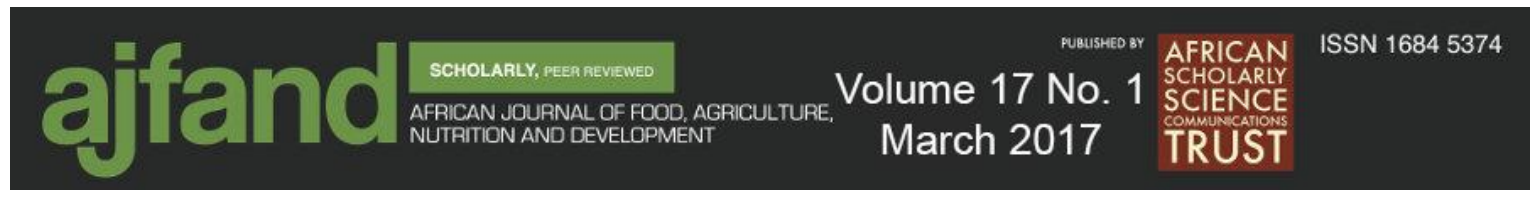

\section{Hazard Identification}

Hazards are any chemical, biological, or physical substance or property that could render food unsafe for consumption [15]. Hazard analysis refers to the process of the evaluation of all the potential hazards and deciding on which ones are significant as to be controlled by a HACCP plan. Hazard analysis consists of two main steps. Step one involves the identification of the potential threats to human health based on the production conditions of the premise and including raw materials and ingredients. The threats include those which may be introduced into the chicken meat product during processing or those associated with the raw material, upcoming ingredients used in processing and dressing of poultry at the premise [16]. The second step involves identification of a critical step at which a specific control must be applied to prevent, eliminate or reduce the occurrence of the specific hazard to an acceptable level [17].

\section{Critical Control Point (CCP) determination}

A HACCP plan requires the development of a $\mathrm{CCP}$ which is defined as a step in the process at which a control measure must be applied to prevent occurrence of, eliminate, or reduce the risk of occurrence of a hazard to an acceptable level [18]. In the identification of CCPs, experts recommend the use of a given set of questions to help in the decision-making process $[19,20]$. These questions constitute the decision tree. Figure 2 presents the Decision Tree for identification of CCPs for the raw materials and ingredients.

Q1. Is there a hazard associated with this raw material?

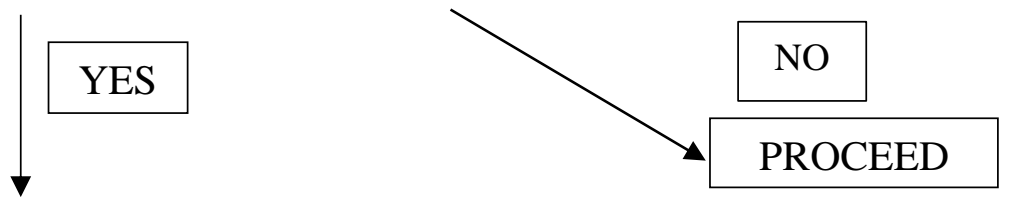

Q2. Is this hazard going to be exposed to any form of further processing?
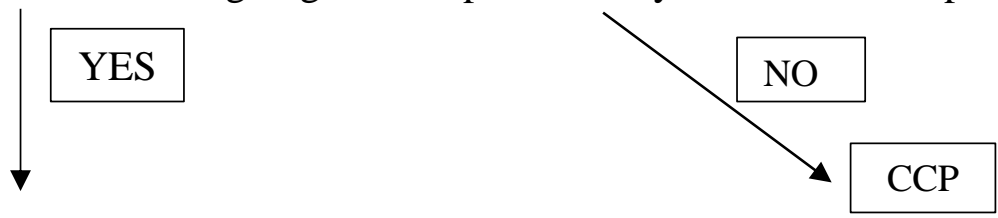

Q3. Is there a cross-contamination risk to the facility or to other products which will not be controlled?
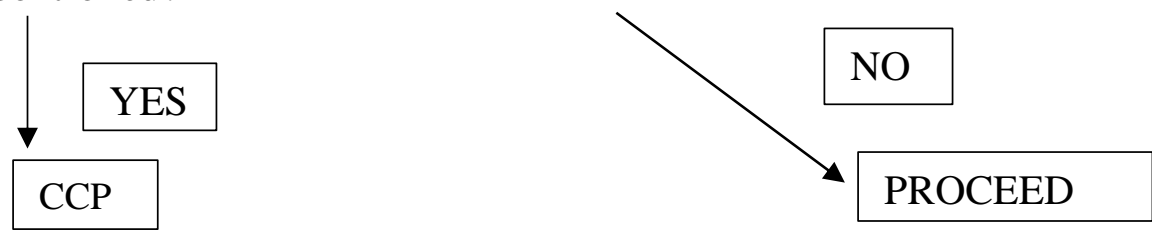

Figure 2: The decision tree for identification of critical control points (CCPs) for the raw materials and ingredients

The decision tree Figure (2) was used to identify the CCPs for the raw materials listed in Table II, while the decision tree in Figure 3 was used to identify CCPs for process steps in Table III.

Source: Khaliduzzaman, 2015, with modification [16] 


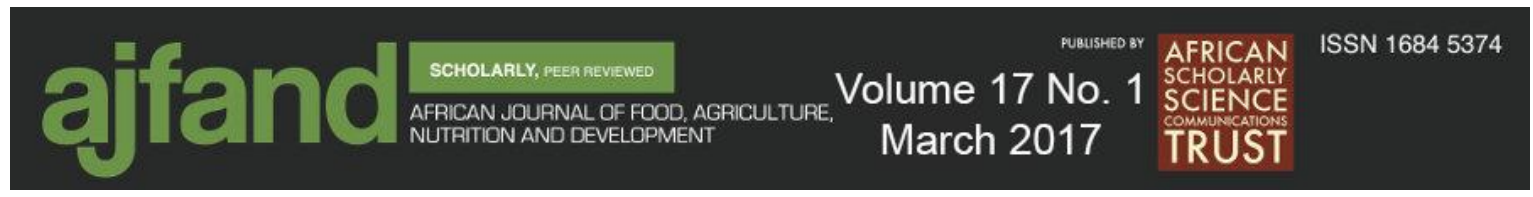

\section{Decision matrix questions for Process Step:}

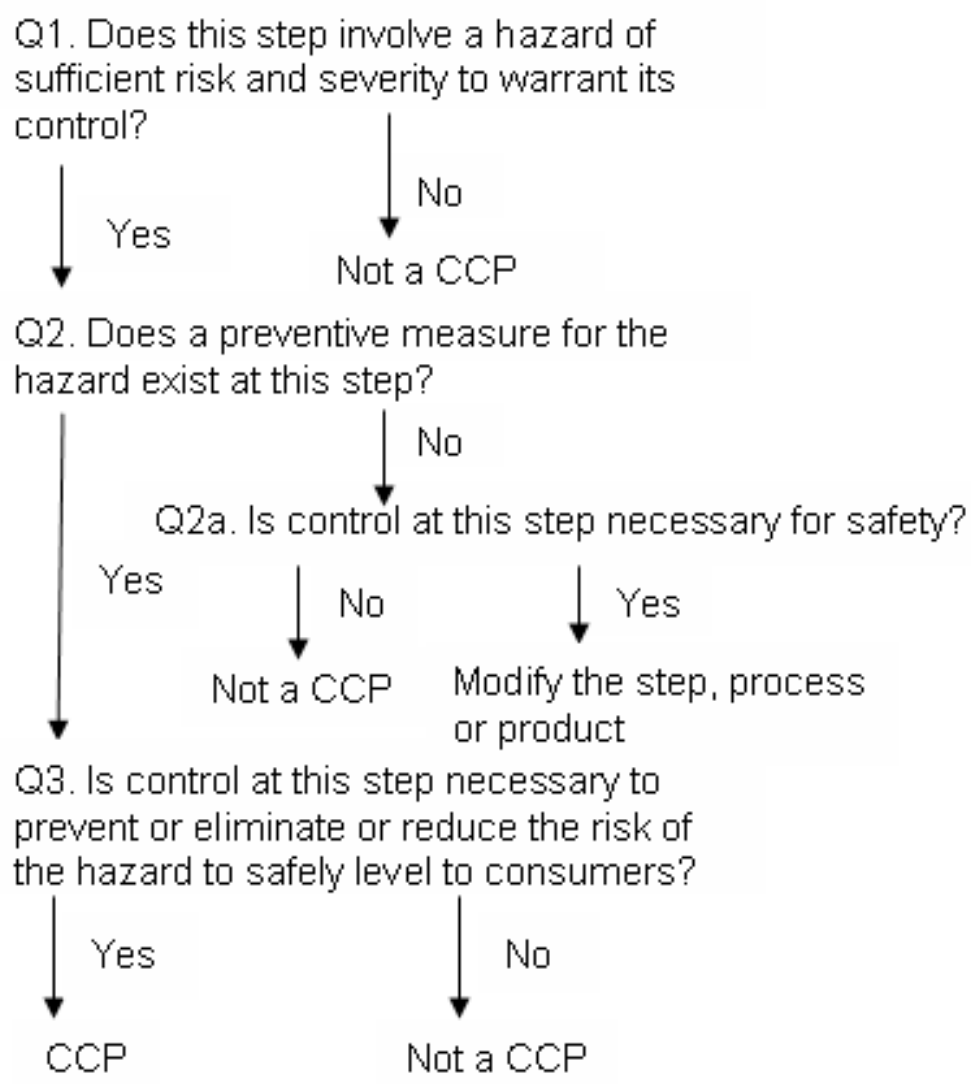

Figure 3: The decision tree for identification of CCPs for the process steps Source: Khaliduzzaman, 2015, with modification [16]

\section{DISCUSSION}

\section{HACCP PLAN}

The HACCP control chart (Table IV) gives an organized list of the hazards and documents all the CCPs, which is the most important document of the HACCP plan. By enumerating any step as a CCP it follows that the process will be emphasized and scrutinized during production [1]. Table IV shows all the potential hazards and classification, in terms of chemical (C), physical (P) or biological (B), at the process steps at which they could occur, and the number of CCPs so that it is specific and documented. The following CCPS were identified: the HACCP control chart, further gives the critical limits, monitoring procedures, frequencies of monitoring, preventive measures, and corrective action for all the hazards listed. Finally, it presents the documented records, the persons responsible and the verification procedures. The CCPs were identified in the raw material especially on reception of chicken with possible contamination of antibiotic and pesticide residues as well as on the process steps. Another CCP was identified as occurrence of toxic chemicals in packaging material. On the process steps, the reception, final rinsing and display/dispatch process steps were noted as CCPs. Earlier, Burson 


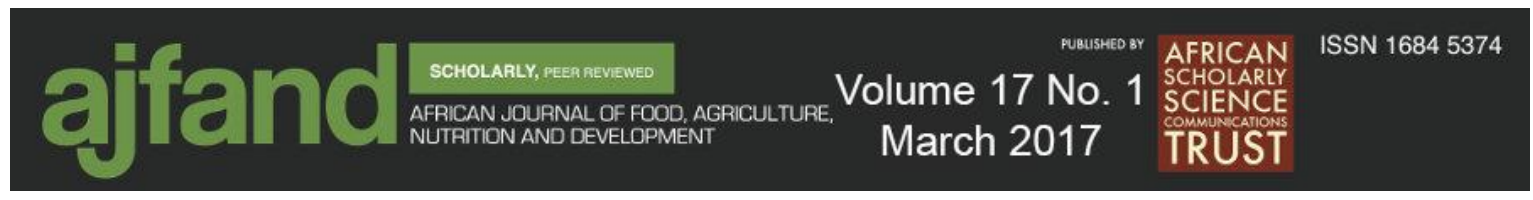

reported the process step records and procedures for verification in their developed control chart for meat products [21]. Zhao reported the process steps in the HACCP plan that is similar to the findings in this study [9]. Codex advises on the importance of monitoring and documentation procedures in a HACCP plan for meat and meat products [17].

From this study, the various monitoring procedures for the different hazards at CCPs are presented in the HACCP plan. The importance of development of monitoring procedures was advocated by Northcutt and Russel [22]. In considering monitoring procedures, emphasis was put on those methods that are implementable and appropriate for online use [23]. All the three CCPs had monitoring procedures. The CCP1 was identified at reception and the target hazard as residues of antibiotics. This was based on experiences where the veterinary officers and traders have reported incidences where ignorant farmers have presented for slaughter chicken treated and before the withdrawal period of the drugs lapsed. In many studies, the maximum residue limits (MRLs) are cited by many companies as the critical limit [24]. However, under the circumstances, regular analysis of MRLs would not suffice due to costs involved. Instead, a due diligence form followed by a certification from the veterinary officer in charge was adopted. The critical limit was zero acceptance of any lot of chicken without a certificate. Monitoring procedures were outlined as inspection of the certificate of compliance. Verification of the effectiveness of this CCP1 was designed to involve quarterly checks on MRLs, and the regular check on the records of certificate of compliance right before dispatch.

The second Critical Control Point (CCP2) was identified at the final rinse step. The responsibility for ensuring safety of a product lies with the manufacturer rather than on the consumer of the said product. Since there is no heat treatment on chicken meat carried out at the slaughter house, the final rinse process provides the only opportunity for reducing or eliminating any pathogens that may be present on the surfaces as well as on the product. The critical limit was set at none detected for pathogenic microorganisms, especially E.coli in any lot of chicken. Observing the strength of the residual chlorine in the final rinse water provided a system of monitoring. Verification of the effectiveness of this process was based on the inspection of the final rinse water records, and the routine use of chlorine test strips [24].

The third Critical Control Point (CCP3) was identified as possible toxic chemicals in the packaging material. This is a critical step because any such toxicity will end up in the plate of consumers. To ensure that all the packaging material used gives no chance for contamination, it is best to pre-qualify the suppliers of the packaging material. This way, only those who can produce material safety data sheets (MSDS) that are acceptable should be given the responsibility to supply. By monitoring every supply to ensure only pre-qualified supplies are received, the threat can be adequately monitored and abated [16]. The continuity of this will be verified through the quarterly supplier audits and review of all relevant records. The CCP4 was identified at the display and dispatch of dressed carcass. Literature and experience indicates that there is a possibility of cross contamination with pathogens when temperatures rise beyond $4^{\circ} \mathrm{C}$ for chicken products [25]. To monitor the temperature, a thermometer and a temperature monitoring device was to be installed. The effectiveness of this CCP was to be verified based on the daily 


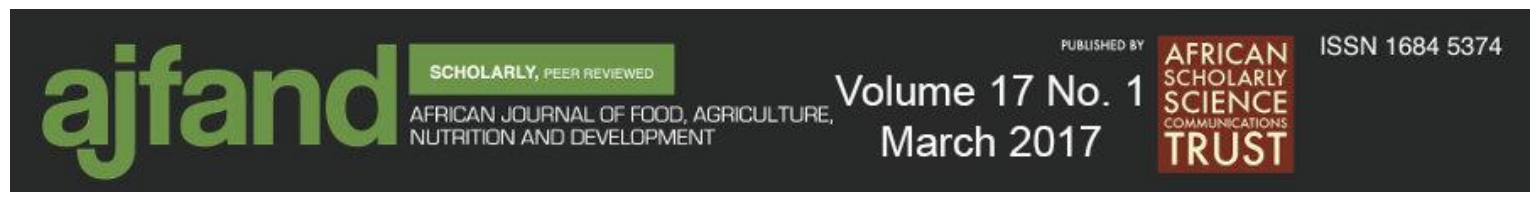

calibration of the thermometer, the review of all temperature logs before dispatch, and reading of the product temperature once per lot/batch. Verification of the implementation of the HACCP programme is critical to success of HACCP and should equally be a role played by the regulatory agencies [15].

\section{CONCLUSIONS}

The implementation of a HACCP system still presents the best way for assurance of safe meat and poultry products. In this study, the crucial need for existence and operationalization of GMPs and Standard Sanitation Operation Procedures (SSOP) was revealed and hence the suggestions for improvement of premises to support these basic tenets of a HACCP plan. The study was conducted to develop a HACCP plan based on the process conditions of the premise. The product description was done to alert consumers of the nature of products, hence the potential hazards in the final product, and how to handle it in a manner to prevent their occurrence. Potential hazards were recorded both in the raw materials as well as in the process steps and relevant control measures presented. The decision tree was then used to identify the CCPs. A HACCP control chart was finally drawn for the processing of indigenous chicken at the poultry slaughterhouse based on all the principles of HACCP. Four CCPs were identified: supply and reception of raw material, supply of packaging material, final rinsing of carcass, and low temperature storage of carcass during display and dispatch. The authors are keen to write a follow up paper upon full implementation of the HACCP plan. County governments that desire to invest in the processing of indigenous chicken in Kenya should be ready and willing to invest in the design of and facilitate the implementation of a HACCP system for the slaughter houses they set up. This will evidently improve the safety of the indigenous chicken meat.

\section{ACKNOWLEDGEMENTS}

This work was made possible through the generous support of Indigenous Chicken Improvement Programme (INCIP) Egerton University, National Commission for Science, Technology and Innovations (NACOSTI), and the Department of Dairy and Food Science and Technology of Egerton University. 


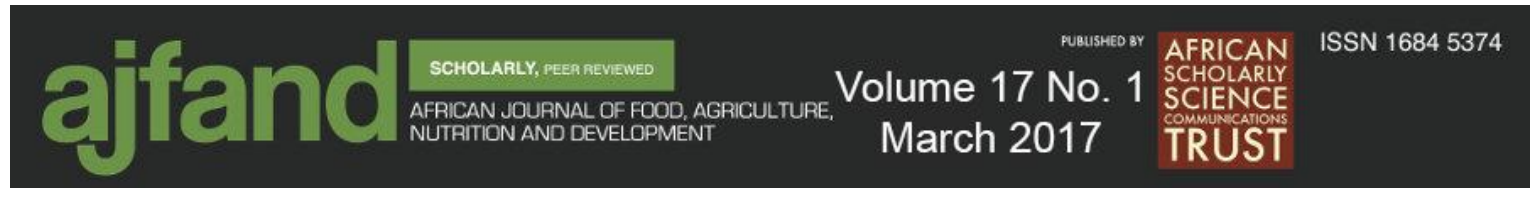

Table I: Detailed summary of the product description record

\begin{tabular}{|c|c|c|}
\hline$\#$ & Item & Description \\
\hline 1 & Common name & $\begin{array}{l}\text { Dressed indigenous chicken (Kuku } \\
\text { kienyeji) }\end{array}$ \\
\hline 2 & How is it to be used? & Ready to cook carcass and parts \\
\hline 3 & Type of packaging & $\begin{array}{l}\text { Carcass packed individually or in parts } \\
\text { in sealed polythene bags or boxed in } \\
\text { bulk }\end{array}$ \\
\hline 4 & Shelf-life & $\begin{array}{l}3-6 \text { months at }-18^{\circ} \mathrm{C} \text { or refrigerated at } \\
\text { below } 4^{\circ} \mathrm{C} \text { for } 7 \text { days }\end{array}$ \\
\hline 5 & $\begin{array}{l}\text { Where will it be sold? Consumers or } \\
\text { intended use }\end{array}$ & $\begin{array}{l}\text { Hotels, restaurants, wholesale to } \\
\text { distributors, retailers and to individual } \\
\text { consumers }\end{array}$ \\
\hline 6 & Labeling instruction & $\begin{array}{l}\text { Safe food handling labels (keep } \\
\text { refrigerated or frozen; cook thoroughly } \\
\text { before eating) }\end{array}$ \\
\hline 7 & Is special distribution control needed? & Keep refrigerated or frozen \\
\hline
\end{tabular}




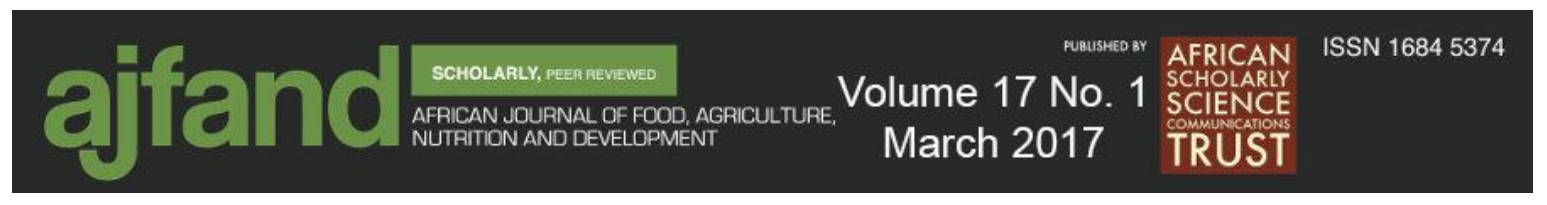

Table II: Raw materials and ingredients Decision Matrix

\begin{tabular}{|c|c|c|c|c|c|c|c|}
\hline $\begin{array}{l}\text { Materials and } \\
\text { Ingredients }\end{array}$ & Hazard & Class & Q1 & Q2 & Q3 & $\mathbf{C C P}$ & Remarks \\
\hline \multirow[t]{3}{*}{$\begin{array}{l}\text { Raw material } \\
\text { (Indigenous chicken) }\end{array}$} & Pathogen & $\mathrm{B}$ & $\mathrm{Y}$ & $\mathrm{Y}$ & $\mathrm{N}$ & Not CCP & $\begin{array}{l}\text { Scalding temperatures would kill external } \\
\text { pathogens/Chlorinated portable rinse water will keep } \\
\text { off pathogens. }\end{array}$ \\
\hline & $\begin{array}{l}\text { Antibiotics \& } \\
\text { pesticide residues }\end{array}$ & $\mathrm{C}$ & $\mathrm{Y}$ & $\mathrm{N}$ & & $\mathrm{CCP} 1$ & $\begin{array}{l}\text { Certificate of inspection of chicken by } \\
\text { approved/registered government officer. }\end{array}$ \\
\hline & Foreign matter & $\mathrm{P}$ & $\mathrm{Y}$ & $\mathrm{Y}$ & $\mathrm{N}$ & Not CCP & $\begin{array}{l}\text { De-feathering/plucking and physical inspection and } \\
\text { personnel hygiene. }\end{array}$ \\
\hline \multirow[t]{2}{*}{ Process Water } & Chlorine residues & $\mathrm{C}$ & $\mathrm{N}$ & & & Not CCP & Chlorine residue test reports. \\
\hline & Pathogen & $\mathrm{B}$ & $\mathrm{N}$ & & & Not CCP & $\begin{array}{l}\text { Water testing sample reports and records of water } \\
\text { treatment by the county government. }\end{array}$ \\
\hline \multirow[t]{2}{*}{ Packaging material } & Toxic Ingredients & $\mathrm{C}$ & $\mathrm{Y}$ & $\mathrm{N}$ & & $\mathrm{CCP} 2$ & $\begin{array}{l}\text { Supply of quality packaging material is critical } \\
\text { (approved suppliers). }\end{array}$ \\
\hline & Foreign matter & $\mathrm{P}$ & $\mathrm{Y}$ & $\mathrm{Y}$ & & Not CCP & $\begin{array}{l}\text { Physical examination/inspection and personnel } \\
\text { hygiene. }\end{array}$ \\
\hline
\end{tabular}

Legend: B -Biological; C-Chemical; P-Physical: Y-Yes; N-No; CCP-Critical Control Point 


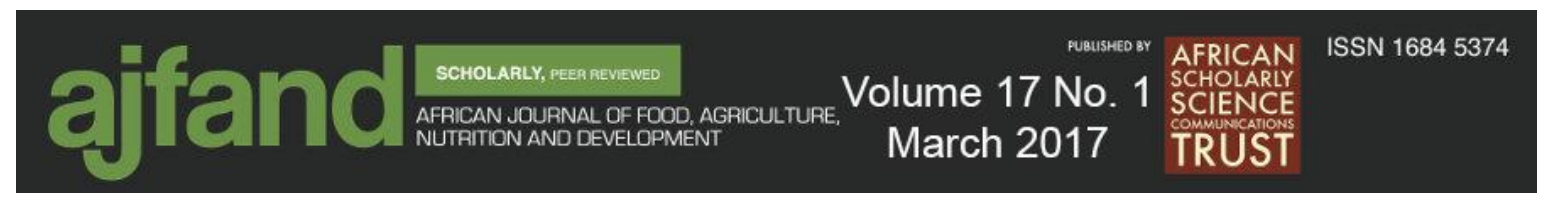

Table III: Decision matrix for Process Steps

\begin{tabular}{|c|c|c|c|c|c|c|c|c|}
\hline Process step & Hazard & Class & Q1 & Q2 & Q2a & Q3 & CCP & Remarks \\
\hline \multirow[t]{3}{*}{ Reception } & $\begin{array}{l}\text { Pesticide /antibiotics } \\
\text { residues }\end{array}$ & $\mathrm{C}$ & $\mathrm{Y}$ & $\mathrm{Y}$ & & $\mathrm{Y}$ & CCP1 & $\begin{array}{l}\text { Inspection of individual chicken by a qualified } \\
\text { government veterinary officer followed by } \\
\text { issuance of certificate of clearance }\end{array}$ \\
\hline & Pests and rodents & $\mathrm{B}$ & Y & $\mathrm{Y}$ & & $\mathrm{N}$ & Modify step & \\
\hline & Pathogens (E.coli) & $\mathrm{B}$ & Y & $\mathrm{N}$ & $\mathrm{N}$ & & Not a CCP & \\
\hline \multirow{5}{*}{$\begin{array}{l}\text { First } \\
\text { Inspection } \\
\text { Holding in } \\
\text { cages }\end{array}$} & None & & & & & & & \\
\hline & Salmonella/S. aureus & $\mathrm{B}$ & Y & $\mathrm{N}$ & $\mathrm{Y}$ & & Modify step & $\begin{array}{l}\text { Only healthy birds are collected and caged. } \\
\text { Cleaning and disinfection of cages at least } \\
\text { twice a day and records kept }\end{array}$ \\
\hline & Dust, soil, & $\mathrm{P}$ & Y & $\mathrm{Y}$ & & $\mathrm{N}$ & Modify steps & $\begin{array}{l}\text { Cleaning and disinfection of cages at least } \\
\text { twice a day and records kept and personal } \\
\text { hygiene }\end{array}$ \\
\hline & Droppings & $\mathrm{P}$ & Y & $\mathrm{Y}$ & & $\mathrm{N}$ & Not CCP & $\begin{array}{l}\text { Cleaning and disinfection of cages at least } \\
\text { twice a day and records kept }\end{array}$ \\
\hline & Foreign matter & $\mathrm{P}$ & $\mathrm{N}$ & & & & & $\begin{array}{l}\text { Cleaning and disinfection of cages at least } \\
\text { twice a day and records kept }\end{array}$ \\
\hline \multirow{2}{*}{$\begin{array}{l}\text { Second } \\
\text { Inspection } \\
\text { Slaughter }\end{array}$} & None & & & & & & & \\
\hline & Salmonella and E.coli & $\mathrm{B}$ & $\mathrm{Y}$ & $\mathrm{N}$ & & $\mathrm{N}$ & Not CCP & $\begin{array}{l}\text { All workers must take medical examinations } \\
\text { from Government health facilities and produce } \\
\text { valid food handlers' certificate before being } \\
\text { allowed to step into the slaughter house }\end{array}$ \\
\hline
\end{tabular}




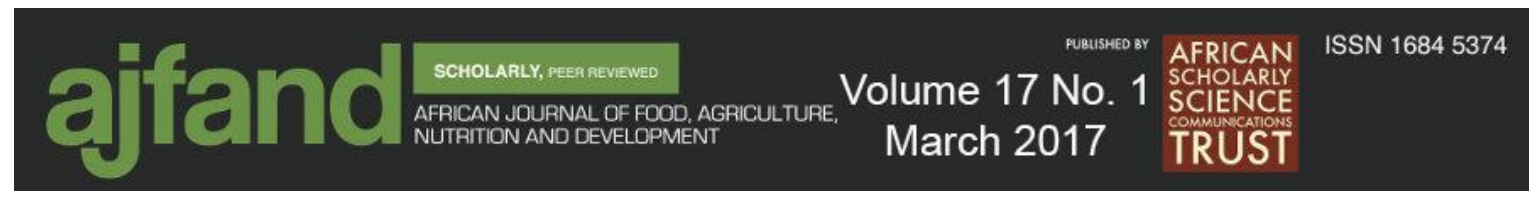

Detergent residues

Blood

Blood clots in veins hence (pathogenic microorganisms' growth).

Scalding Smoke

Peeled skin

No

Dirt
Y N

Y Y
Modify step

Not a CCP

Modify Step bleeding procedures and inspected by Quality Assurance Manager /Quality control (QC)officer/veterinarian and records kept

Modify step Modify step to use electricity and other nonsmoke producing sources of energy

Proper timing and temperature of the scalding w: and a monitoring device and records kept. The scalding temperature be monitored/controlled by temp probe inserted into the scald tank near the $\mathrm{r}$ exit

Modify Step Regular change of scalding water and records

kept

N Not a CCP
Proper timing and temperature of scalding water (records). Correct procedure and pressure for de-feathering and inspected by the QC in charge and records kept. Observe Personnel hygiene 


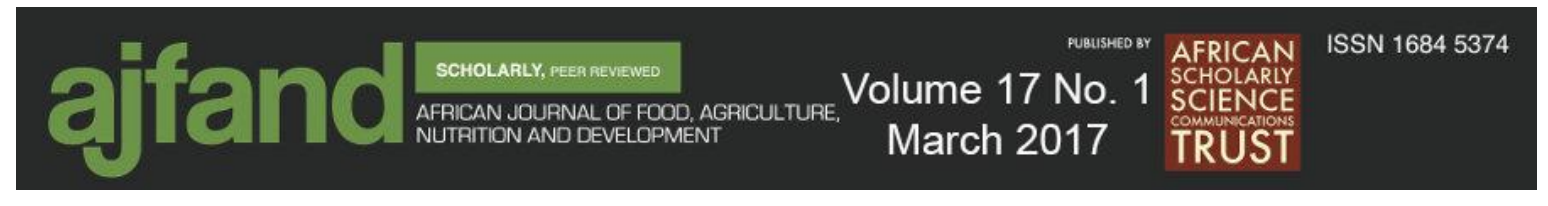

Damaged skin

\section{Metal chippings}

head/limbs

Detergent residues

\begin{tabular}{|c|c|}
\hline Evisceration & $\begin{array}{l}\text { Pathogens (fecal and } \\
\text { ingest contamination } \\
\text { from gut } \\
\text { breakage). } \text { Intestinal } \\
\text { contamination (E.coli, } \\
\text { Salmonella, } \\
\text { Campylobacter) }\end{array}$ \\
\hline Washing & $\begin{array}{l}\text { Detergent residues } \\
\text { Chorine residues }\end{array}$ \\
\hline
\end{tabular}

Foreign matter (feathers, skin, dirt)

Final rinse
B

$\mathrm{P}$

Y

$\mathrm{N}$

Y $\quad \mathrm{Y} \quad \mathrm{N}$

B

$\begin{array}{lll}\mathbf{Y} & \mathbf{N} & \mathbf{Y}\end{array}$

$\begin{array}{lll}\mathrm{C} & \mathrm{Y} & \mathrm{Y}\end{array}$

C $\quad$ Y $\quad$ Y

$\mathrm{N}$

P N

P N

Chlorine residue
Not a CCP

Not CCP

Not CCP

Not CCP modify the steps

Not CCP

$\mathrm{N} \quad \mathrm{Not} \mathrm{CCP}$

Not CCP

Not a CCP

Modify the process step
Correct procedure and pressure for $\mathrm{d}$ feathering and inspected by the QC in charge and records kept

Use of stainless steel knives and inspection of the knives at least twice a day and records kept

Training of personnel on proper cleaning \& rinsing procedures rinsing records kept

Proper setting of evisceration equipment. Training presentation on evisceration procedure and training records kept. Visual examination of carcass for fecal contamination. Maintenance of correct strength of chlorination for the rinse water

Final rinse water strength is crucial

Determination of chlorine residue on a quarterly basis and records kept

Visual examination of carcass for any foreign matter and inspection rerecords kept

Visual exam will ensure no foreign matter goes beyond this process 


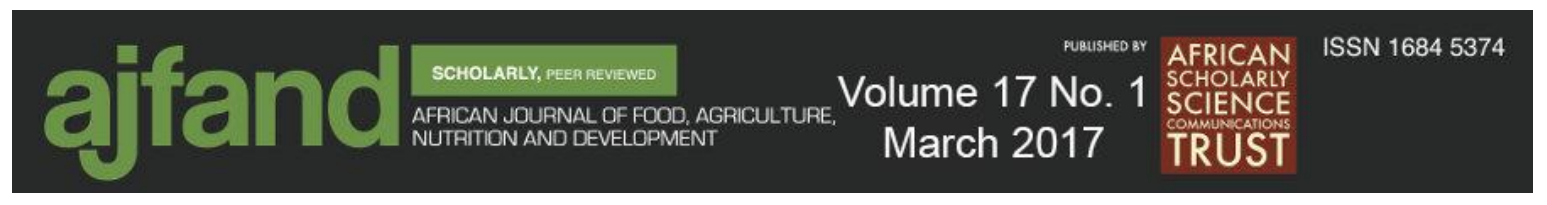

\section{Draining of Residual rinse water in $\mathrm{P} \quad$ No water}

Training presentation on correct drainage of carcass and inspection of carcass for proper drainage before rereleased

\section{Labelling}

Inspection/vet Ink

officer

stamping

$\begin{array}{llllllll}\begin{array}{l}\text { Packaging } \\ \text { material }\end{array} & \text { Toxic material } & \text { C } & \text { Y } & \text { N } & & \text { CCP3 } \\ \begin{array}{l}\text { Display, } \\ \text { dispatch }\end{array} & \begin{array}{l}\text { Biological }(\text { E.coli, } \\ \text { Salmonella and } S .\end{array} & & \text { Y } & \text { Y } & & \text { Y } & \text { CCP4 } \\ \text { aureus }) & & & & & \end{array}$

$\begin{array}{ll}\text { None } & \\ \mathrm{P} & \text { No }\end{array}$

\author{
Possibility of toxic material persists and must \\ be control through HACCP plan \\ Proper chilling of product to prevent \\ proliferation of pathogenic bacteria. \\ Installation of a chilling monitoring equipment
} $(\log )$ 


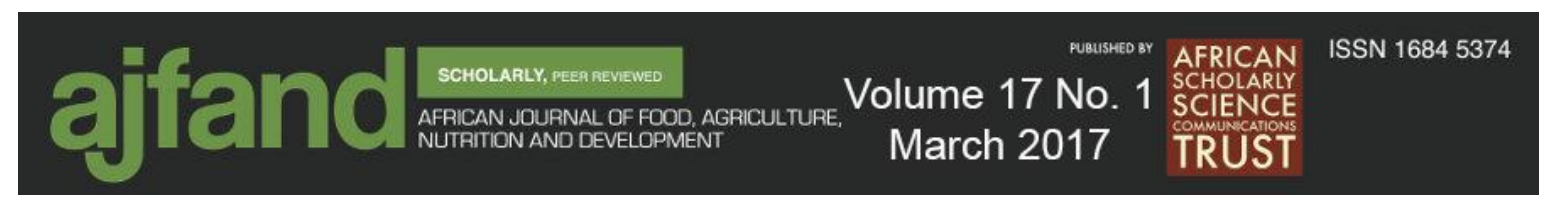

Table IV: HACCP Plan for Indigenous Chicken Processed at a Slaughterhouse in Nakuru

\begin{tabular}{|c|c|c|c|c|c|c|c|c|c|c|}
\hline $\begin{array}{l}\text { CCP } \\
\text { No s }\end{array}$ & $\begin{array}{l}\text { Process } \\
\text { Step; }\end{array}$ & Hazard & Critical Limits & Monitoring Procedure & Frequency & Preventive measure & Corrective action & Record & $\begin{array}{l}\text { Responsible } \\
\text { person }\end{array}$ & Verification Procedures \\
\hline $\begin{array}{l}\text { CCP } \\
\text { No } 1\end{array}$ & $\begin{array}{l}\text { Receptio } \\
\mathrm{n}\end{array}$ & $\begin{array}{l}\text { Antibiotic } \\
\text { residues }\end{array}$ & $\begin{array}{l}\text { No chicken } \\
\text { delivered within } \\
\text { recommended } \\
\text { days of } \\
\text { withdrawal }\end{array}$ & $\begin{array}{l}\text { Inspection of certificate } \\
\text { of compliance for every } \\
\text { batch signed by an } \\
\text { authorized veterinary } \\
\text { officer }\end{array}$ & $\begin{array}{l}\text { Every } \\
\text { delivery }\end{array}$ & $\begin{array}{l}\text { Withholding the flock } \\
\text { awaiting approval of an } \\
\text { authorized veterinary officer }\end{array}$ & $\begin{array}{l}\text { Reject the batch if } \\
\text { the certificate of } \\
\text { compliance is not } \\
\text { produced }\end{array}$ & $\begin{array}{l}\text { Certificate of } \\
\text { compliance } \\
\text { Records }\end{array}$ & $\begin{array}{l}\text { QA officer in } \\
\text { charge }\end{array}$ & $\begin{array}{l}\text { Check the certificate of } \\
\text { compliance records/get } \\
\text { quarterly MRLs reports from } \\
\text { accredited laboratories }\end{array}$ \\
\hline $\begin{array}{l}\text { CCP } \\
2\end{array}$ & $\begin{array}{l}\text { Final } \\
\text { Rinse }\end{array}$ & $\begin{array}{l}\text { Pathogens } \\
\text { (E.coli, } \\
\text { Salmonella, } \\
\text { Campylobact } \\
\text { er) } \\
\end{array}$ & $\begin{array}{l}\text { Residual chlorine } \\
\text { of } 50 \mathrm{ppm}\end{array}$ & $\begin{array}{l}\mathrm{pH} \text { and Chlorine residue } \\
\text { measurements using the } \\
\text { strips }\end{array}$ & $\begin{array}{l}\text { After every } \\
\text { batch/lot of } \\
\text { chicken }\end{array}$ & Withhold the carcass, & $\begin{array}{l}\text { Re-adjust } \\
\text { chlorinator and } \\
\text { take samples to } \\
\text { confirm full } \\
\text { operationalization }\end{array}$ & $\begin{array}{l}\text { Final } \\
\text { rinse/carcass } \\
\text { quality records }\end{array}$ & $\begin{array}{l}\text { QA/C officer } \\
\text { in charge }\end{array}$ & $\begin{array}{l}\text { Verify final rinse water } \\
\text { quality records/daily residual } \\
\text { chlorine checks/titration and } \\
\text { Obtain quarterly chlorine } \\
\text { analysis reports }\end{array}$ \\
\hline $\begin{array}{l}\mathrm{CCP} \\
3\end{array}$ & $\begin{array}{l}\text { Packagin } \\
\mathrm{g} \\
\text { material }\end{array}$ & $\begin{array}{l}\text { Toxic } \\
\text { materials }\end{array}$ & $\begin{array}{l}\text { No unqualified } \\
\text { product used }\end{array}$ & $\begin{array}{l}\text { Supplier audits and } \\
\text { quality assurance }\end{array}$ & $\begin{array}{l}\text { Each } \\
\text { supply }\end{array}$ & $\begin{array}{l}\text { Qualified packaging } \\
\text { material supplied and proof } \\
\text { of check of MSDS; } \\
\text { approved supplier list and } \\
\text { specifications agreed }\end{array}$ & $\begin{array}{l}\text { Change supplier or } \\
\text { brand of non- } \\
\text { conforming } \\
\text { material }\end{array}$ & $\begin{array}{l}\text { Raw material } \\
\text { reception } \\
\text { records }\end{array}$ & $\begin{array}{l}\text { QA/C officer in } \\
\text { charge }\end{array}$ & $\begin{array}{l}\text { Verify list of qualified } \\
\text { suppliers, conduct regular } \\
\text { supplier audits, and check } \\
\text { MSDS for every material }\end{array}$ \\
\hline $\begin{array}{l}\text { CCP } \\
4\end{array}$ & $\begin{array}{l}\text { Display/ } \\
\text { Dispatch }\end{array}$ & $\begin{array}{l}\text { Pathogens } \\
\text { (E.coli, } \\
\text { Salmonella, } \\
\text { Campylobact } \\
\text { er) }\end{array}$ & $\leq 4^{\circ} \mathrm{C}$ for 7 days & $\begin{array}{l}\text { A calibrated thermometry } \\
\text { and a temperature coding } \\
\log \end{array}$ & $\begin{array}{l}\text { Internal } \\
\text { temperature } \\
\text { to reach } \\
4^{\circ} \mathrm{C} \text { in } 4 \mathrm{hrs} \\
\text { after } \\
\text { processing }\end{array}$ & $\begin{array}{l}\text { Withhold product, and } \\
\text { adjust the temperature to the } \\
\text { correct reading for the } \\
\text { adequate amount of time }\end{array}$ & $\begin{array}{l}\text { Freeze product } \\
\text { and observe as an } \\
\text { internal } \\
\text { temperature of } 4^{\circ} \mathrm{C} \\
\text { is arrived at }\end{array}$ & $\begin{array}{l}\text { Dispatch } \\
\text { records/Final } \\
\text { product } \\
\text { temperature } \\
\text { logs and } \\
\text { records }\end{array}$ & $\begin{array}{l}\text { QA/C officer in } \\
\text { charge }\end{array}$ & $\begin{array}{l}\text { Review the temperature logs } \\
\text { daily/before dispatch. } \\
\text { Calibrate thermometer daily. } \\
\text { Check and record temp once } \\
\text { per batch }\end{array}$ \\
\hline
\end{tabular}

CCP-Critical control point

QA/C-Quality Assurance/Control

MSDS-material safety data sheets

MRL- Maximum residue limits 


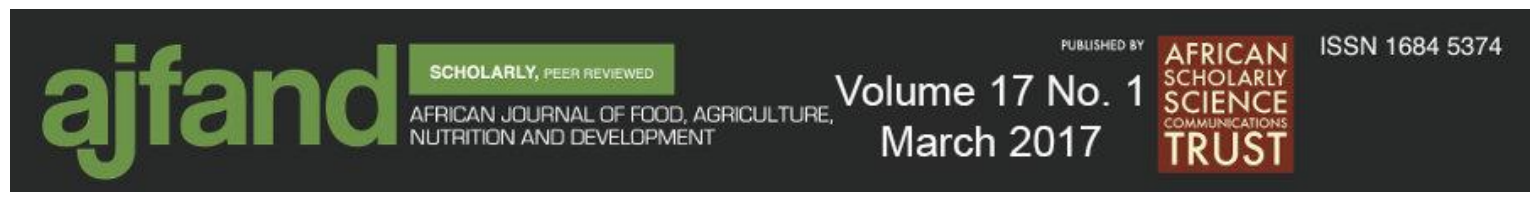

\section{REFERENCES}

1. EL- Hofi M, El-Sayed EL-Tanboly and A Ismail Implementation of the Hazard Analysis Critical Control Point (HACCP), System to UF White Cheese Production Line. Internet Journal of Food Safety. 2008; 10:1-8.

2. National Advisory Committee on Microbiological Criteria for Foods (NACMCF). Hazard Analysis and Critical Control Point system. The National Advisory Committee on Microbiological Criteria for Foods. Journal of Food Microbial. 1992; 16(1).

3. Ropkins $\mathbf{K}$ and AJ Beck Evaluation of Worldwide Approaches to the Use of HACCP to Control Food Safety. Trends in Food Science and Technology, 2000; 11(1): 10-21.

4. International Meat and Poultry HACCP Alliance Generic HACCP Model for Poultry Slaughter. Kansas City, Missouri.1996.

5. Hessing A, Schneider RE, Gutierrez A, Silverberg R, Michael SG and KR Schneider The Cost of Food Safety. U.S. Department of Agriculture, UF/IFAS Extension Service, University of Florida, IFAS, Florida A \& M University Cooperative Extension Program, and Boards of County Commissioners Cooperating. Nick T. Place, dean for UF/IFAS Extension. 2015.

6. $\quad$ Bardic A HACCP Ready. Dairy Field. 2001; 184 (2): 6.

7. Bennet $\mathbf{L}$ and $\mathbf{L}$ Steed An integrated approach to food safety. Quality Programme. 1999; 32: 37-42.

8. Mortimore C and S Wallace HACCP. Chapman \& Hall, New York, USA. 1997.

9. Zhao M The Design of HACCP plan for a small-scale cheese plant. Research Thesis, University of Wisconsin-stout. Menomonie, W1 54751. 2003.

10. Codex Alimentarius Commission. Hazard analysis and critical control point (HACCP) system and guidelines for its application annex to CAC/RCP 1-1969 (rev. 4 - 2003).

11. Wolfgang $\mathbf{R}$, Tschape $\mathbf{H}$ and $\mathbf{A}$ Baumler Non-typhoidal Salmonellosis: emerging problems. Microbes and Infection, 2001;3: 237-247.

12. Jianghong $\mathbf{M}$ and MP Doyle Introduction: Microbiological food safety. Microbes and Infection, 2002; 4: 395-397.

13. Mortimore S How to make HACCP really work in practice. Food Control, 2001;12: 209-215. 


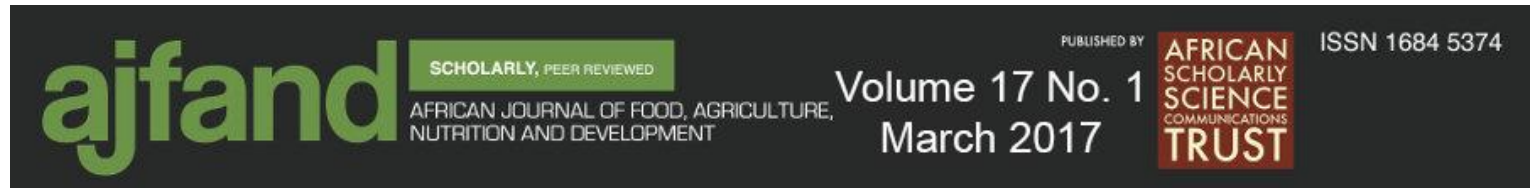

14. Patton QM Qualitative research and evaluation methods ( $3^{\text {rd }}$ Ed). Sage Publications Inc. California. 2003.

15. National Advisory Committee on Microbiological Criteria for Foods (NACMCF). HACCP principles \& application guidelines. U.S. Food and Drug Administration. 2014. Retrieved on $10^{\text {th }}$ of February 2016 from, http://www.fda.gov/food/guidanceregulation/haccp/ucm2006801.htm

16. Khaliduzzaman A Design of HACCP plan for chicken ball plant in Bangladesh. Journal of Hygienic Design and Engineering. 2005.

https://www.google.co.ke/url? sa=t\&rct=j\&q=\&esrc=s\&source=web\&cd=1\&ca $\mathrm{d}=\mathrm{rja} \&$ uact $=8 \&$ ved $=0$ ahUKEwiisrb6N3KAhXKuhQKHfS0DqQQFggaMAA\&url=http\%3A\%2F\%2Fwww.jhed. mk\%2Ffilemanager\%2FJHED\%2520Vol\%25204\%2F01.\%2520FQS\%2F06.\%2 520Full\%2520paper\%2520\%2520Alin\%2520Khaliduzzaman.pdf\&usg=AFQjC NGk7adnTxLlgBZY1KM9v8s0NxFTpg\&bvm=bv.113370389,d.d2s (UDC 637.54'65:006.83(549.3)) Accessed 10 ${ }^{\text {th }}$ November, 2015.

17. Codex Alimentarius Commission HACCP Code of hygiene practice for meat. CAC/RCP. 2005: 58 - 2005.

18. National Board of HACCP Expert. Requirements for a HACCP based food safety system. Option A management system certification. Compiled by National Board HACCP Expert HACCP-The Netherlands. 2006. https://www.google.co.ke/?gws_rd=ssl\#q=General+Guidelines+for+implement ation+National+Board+HACCP+Expert\%2C+2006\%29 $\left(\right.$ Accessed on $11^{\mathrm{h}}$ January, 2016).

19. Codex Alimentarius Commission. Guidelines for application of Hazard Analysis and Critical Control Point (HACCP) system. Codex Aliment. Comm. Food Hyg. WHO/FAO, Switzerland.1993.

20. Riswadkar V An introduction to HACCP the Hazard Analysis and Critical Control Point System for Food Processors. Profess. Safety, 2000; 45: 33-36.

21. Burson DE Hazard Analysis Critical Control Point (HACCP) Model for Frankfurters. University of Nebraska, Lincoln, NE 68583-0908. http://foodsafety.unl.edu/haccp/plans/frankfurters.pdf. Accessed 10th August, 2015. 


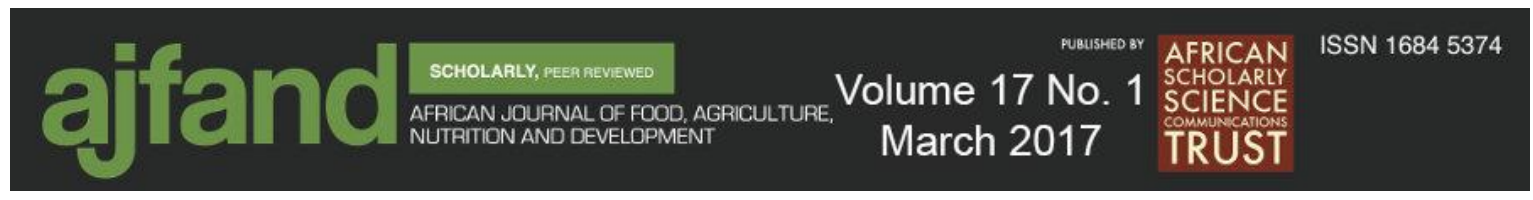

22. Northcutt JK and SM Russel General Guidelines for Implementation of HACCP in Poultry Processing Plant. The Corporative Extension University of Georgia. 2010.

https://www.google.co.ke/url?sa=t\&rct=j\&q=\&esrc=s\&source=web\&cd=1\&ca $\mathrm{d}=$ rja\&uact=8\&ved=0ahUKEwi6wLrv5d3KAhWDvxQKHdB6AOMQFggdM AA\&url=http $\% 3 \mathrm{~A} \% 2 \mathrm{~F} \% 2 \mathrm{Fathenaeum}$. libs.uga.edu $\% 2 \mathrm{Fbitstream} \% 2 \mathrm{Fhandle} \% 2$ F10724\%2F12487\%2FB1155.pdf\%3Fsequence\%3D1\&usg=AFQjCNEePBylT bl3J7CXBipx1Jyqcb9FJA\&bvm=bv.113370389,d.bGQ . (Accessed on 10 January, 2016).

23. Seuli C, Paula T, Carlos A and $\mathbf{O}$ Fernandes de Implementation of HACCP in the Food Industry, Impact on Safety and Environment. Novel technologies in food Science, their impact on products, consumers Trends, and the Environment. Springer. 2015.

24. Mohamed BN and M Jianghong Risk Assessment of Disinfection Byproducts in poultry chilled in chlorinated water. University of Maryland. 2009.

25. Tompkins RB HACCP in the meat and poultry industry. Food Control. 1994; 5 (3):153-169. 